\title{
EVALUATION FOR REBRANDING: THE IMPACT OF LOGO CHANGE ON BRAND ATTITUDE AND BRAND LOYALTY
}

\author{
DOI: 10.17261/Pressacademia.2021.1384 \\ JMML- V.8-ISS.1-2021(2)-p.17-33
}

Hsin-Hung Shen ${ }^{1}$, Chih-Huang Lin ${ }^{2}$

${ }^{1}$ Feng Chia University, Ph.D. Program in Business, No. 100, Wenhwa Rd., Seatwen, Taichung, Taiwan 40724, R.O.C. angel.type@gmail.com, ORCID: 0000-0002-2943-9143

${ }^{2}$ Feng Chia University, Department of Marketing, No. 100, Wenhwa Rd., Seatwen, Taichung, Taiwan 40724, R.O.C. linchihh@fcu.edu.tw, ORCID: 0000-0002-4813-154X

\begin{tabular}{l}
\hline Date Received: January 2, $2021 \quad$ Date Accepted: March 8, 2021 open OACCEss \\
\hline To cite this document \\
Shen, H.H. and Lin, C.H. (2021). An evaluation for rebranding: the impact of logo change on brand attitude and brand loyalty. Journal of \\
Management, Marketing and Logistics (JMML), V.8(1), p.17-33. \\
Permanent link to this document: http://doi.org/10.17261/Pressacademia.2021.1384 \\
Copyright: Published by PressAcademia and limited licensed re-use rights only.
\end{tabular}

\section{ABSTRACT}

Purpose - This research investigated on the issue of Logo change in the rebranding strategy. The rebranding strategy plays an important role in the brand's cycle and enhances the competitiveness continuously. Since brand is one of the most important assets of the company, logo is the core visual factor for customer to recognize, memorize and communicate. Meanwhile, logo is often redesigned along with the adjustment of brand strategy to meet consumers' needs. Therefore, logo change is the most direct and speedy method among the brand strategy which is also the key factor to create another peak of the business and sustain the brand life circle.

Methodology - The study employs the experimentation method of quantitative research to explore how logo change influences the consumer behavior. By analyzing four different scenarios, 2 (Logo Appropriateness: high vs. Low) x 2 (Logo Familiarity: high vs. low) and collecting 460 data from college students, the study will also adopt ANOVA to measure the influence of brand attitude and brand loyalty affected by logo change.

Findings- The result of the study indicates that rebranding is a continuously dynamic cycle which proves a positive impact will be influenced by the logo appropriateness towards to brand attitude and brand loyalty. In other words, when customer view the logo design in line with the meaning of brand, the more familiar with the logo the more positive attitude towards the brand loyalty.

Conclusion- Rebranding strategy aims to sustain the life of brand and the important method to create the peak of innovation continually. Furthermore, the logo change is more direct and speedy way to attract customer attention. Therefore, the contribution of the research will not only make up the gap between the logo design and rebranding research but also provide the best reference for brand managers to upgrade the brand strategy.

Keywords: Rebranding, logo change, logo appropriateness, logo familiarity, brand strategy JEL Codes: M30, M31, M37

\section{INTRODUCTION}

In recent years, many companies have rebranded themselves by changing their names or logos. As brand managers expect that their brands can be revitalized or "reborn" through a Logo change, it has become the preferred method to rebrand companies.

Muzellec and Lambkin (2006) suggested that rebranding refers to creating a new name, slogan, symbol, design, or a combination of them for an established brand. Research on brand Logos has received little attention, and discussions of Logo design or Logo change have even been ignored by many scholars (Kohli and Suri, 2002; Hem and Iversen, 2004). However, a few scholars have begun to explore the relationship between Logo change and consumers; for example, Pimentel and Heckler (2003) found that consumers generally prefer that a Logo does not change, but can tolerate small changes. Walsh et al. (2010) indicated that consumers with a high level of brand commitment have more negative attitudes towards a Logo change, while consumers with a low level of brand commitment have more positive attitudes towards a brand after a Logo change. 
This study starts with rebranding to focus on Logo change issues and confirms the causal relationship between brand attitudes and brand loyalty. Through the discussion of this study, we hope to provide a better decision-making basis and evaluation method reference for brand managers. The specific research objectives are listed, as follows:

(1) To explore the influence of Logo change on brand attitude and brand loyalty in rebranding.

(2) To provide a reference for industries to rebrand through Logo change.

(3) Brand managers can predict the risk of a Logo change, the change of consumers' brand attitude, and brand loyalty through evaluation.

(4) Brand managers can make brand identification decisions more efficiently through the systematic evaluation method presented in this study.

\section{LITERATURE REVIEW AND HYPOTHESIS DEVELOPMENT}

In accordance with the research theme and purpose, this study further reviews literature related to Brand Rebranding, Logo Change, Logo Appropriateness, Logo Familiarity, Brand Attitude, and Brand Loyalty, and develops the research hypotheses.

\subsection{Rebranding}

Rebranding is a normal response to major changes, such as external environment changes and internal structure adjustment, which cannot be avoided by enterprises. Muzellec et al. (2003) argued that rebranding is a series of processes regarding the repositioning, renaming, redesigning, and relaunching of existing brands from the perspective of brand strategy, and obtaining long-lasting brand competitiveness through brand innovation.

Keller (2013) suggested that rebranding is reinforcing and revitalizing the brand, and suggested that brand managers should keep pace with the times and maintain and strengthen the customer-based brand equity. Muzellec et al. (2003) further explained the concept of rebranding, and believed that rebranding is "the practice of re-establishing differentiated name forms in the minds of stakeholders and adopting a unique identity to distinguish them from competitors".

Other concepts similar to rebranding include brand rejuvenation (Lehu, 2004), brand repositioning (Aaker, 2004), brand revitalization (Keller, 1999), brand reinforcement (Keller, 2004 and 1999), and brand rechristening (Kaikati and Kaikati, 2004). At present, the more widely quoted definition in academic circles is the definition put forward by Muzellec and Lambkin (2006), who stated that rebranding is to create a new name, slogan, symbol, design, or a combination of them for an established brand, in order to establish a new image in the minds of internal organizations, external competitors, and stakeholders (Muzellec and Lambkin, 2006). This concept explains the meaning of rebranding from a macro point of view, and emphasizes unique brand identification and the re-establishment of brand image.

Although there are some cognitive differences in the definition of rebranding by many scholars, most of them focus on the organization's brand image, brand recognition, and the re-establishment of the relationship with consumers. Therefore, the meaning of rebranding can be explained from two aspects. One is the external perception of the brand, meaning the brand image; the second is the internal perception of the brand, meaning brand identity. These two perceptions can influence consumers' attitudes towards a brand. Therefore, this study believes that rebranding can be defined as "the process of revising or reestablishing brand image to reflect the change of brand identity".

\subsection{Logo Change}

Among the plentiful literature regarding the reasons for rebranding, it is worth noting that rebranding is not equal to a Logo change. In other words, rebranding does not necessarily involve brand visual adjustment, thus, a Logo change is just one of the many means of rebranding.

As change is continuous in the internal and external environments of enterprises, organizations must be constantly reshaped to conform to the market situation (Banerjee, 2008). In today's business environment, unstable external environments, challenges from competitors, threats from new brands, changes in consumer habits, and other factors become increasingly important for enterprises or brands to survive in the market. Since the visual expression of a Logo comes from the concentration of brand value, a brand Logo may be affected by the changes of external competitive environment or the adjustment of internal brand strategy. 
From a macro point of view, there are many external factors that motivate an enterprise to change its Logo, which can be summed up in three aspects: the changes of economic markets (Kapferer, 2008), the changes of consumer demands (Bolhuis et al., 2018), and adjustments of competition models (Müller et al., 2013).

Pressure from external environments often prompt companies and brands to change their logos. However, Logo changes are more often driven by internal factors, such as business strategy changes (Van Riel and Van Hasselt, 2002), brand image adjustments (Melewar and Akel, 2005), and organizational structure changes (Rosson and Brooks, 2004).

Regardless of internal or external reasons, the market environment is always changing; therefore, the development of a brand can be said to be a dynamic process. Brand managers must occasionally reshape the brand, and constantly readjust its image to meet the changing times and needs of consumers.

\subsection{Logo Appropriateness}

"Which Logo has the best design?" This is a meaningless question for a brand manager, because if 10 designers are commissioned, 10 "best" logos will be received, and this is the most elusive part of a Logo design. Interestingly, the same design subject (brand) may have different results under different design interpretations. Therefore, the goal is not to find "the best", but determine "which logo has the most appropriate design".

Although the subjectivity of visual aesthetics in Logo designs often confuse brand managers, it is not difficult to assess whether a Logo is appropriate or not. In terms of results, a proper Logo has its basic functions and measurable dimensions that must be fulfilled; for example, Haig and Harper (1997) argued that an ideal Logo should be appropriate, interesting, and unique, in addition to reflecting the expertise and trustworthiness of a company. Hem and Iversen (2004) indicated that a good Logo must be recognizable, meaningful, and affective.

In terms of specific functions, Adams $(2008$, p.9) suggested that a Logo can help brands differentiate from competition, create a focus internally, provide clear identification, enable the audience to form a personal relationship, create merchandising opportunities, create credibility, bring order to chaos, and communicate a message.

However, the appropriateness of the design aesthetic does not equal the quality of the work (Frascara, 1988). In other words, whether the meaning of the brand is consistent with the form of the Logo requires special attention (Molenaar, 2015). Molenaar (2015) divided Logos into traditional and modern logos, as based on the evaluation of the shape, font, color, and other elements. However, neither of these two types of logos are superior to the other, and the key point is whether the style is consistent with the target recognition set by the brand.

Based on the viewpoints of the above scholars, this study refers to the viewpoints of Doyle and Bottomley (2004) regarding the study of different font appropriateness of brand names, and defines Logo appropriateness as "whether the Logo appropriately represents the brand's inherent value and immediate value". In terms of the assessment of appropriateness, this study refers to the functional and sensory-social aspects applied by Bottomley and Doyle (2006).

\subsection{Logo Familiarity}

Brand familiarity can provide external clues for consumers to make purchase decisions and is an important factor affecting consumer behavior. Consumers will gradually form brand familiarity through purchasing or using, advertising, recommendations from others, and viewing channels. After accumulating a certain degree of familiarity, consumers will have different degrees of association with the brand, and may start to use the brand they are familiar with. In other words, consumers' familiarity with the brand will be highly correlated with the brand they eventually choose (Haley and Case, 1979). Bettman and Sujan (1987) also believed that consumers would have a stable preference for familiar brands, as they have established experience and association related to the brand. On the contrary, consumers' preference for unfamiliar brands is not obvious because they have not formed an attitude or have a weak attitude towards them (Fazio, 1986). According to the above scholars' conclusions, if consumers can have a series of associations and memories when they see the brand logo, it can greatly improve the chances of them buying the brand, which is also an important reason for brand managers to improve the familiarity of the Logo.

At present, there few studies on Logo familiarity; for example, Chadwick and Walters $(2009$, p.71) found that a Logo can effectively improve the recognition, familiarity, and appreciation of a brand. Melewar and Saunders (1998) found that the standardization of the visual system of an enterprise is conducive to the improvement of its product and brand familiarity. Kent and Allen (1994) suggested that a brand should make good use of its Logo and color to communicate with consumers, in order to enhance the brand's attention and advantages. 
As a Logo that looks familiar is often perceived by consumers more quickly, and has an impact on the quality cognition of the brand or product (Henderson et al., 2003), Logo familiarity can improve the effect of a Logo, benefit the brand more, and have further positive impact (Hem and Iversen, 2004; Van der Lans et al., 2009). In another empirical study, Peterson et al. (2015) proposed that consumers' familiarity with a Logo would have a more positive impact on their cognition of the extent of Logo modification. In other words, the more familiar consumers are with a Logo, the more likely they are to notice the difference in the changed Logo.

\subsection{Brand Attitude}

Consumers have their subjective preferences or attitudes towards brands, and these attitudes or evaluations will further affect their consumption behaviors. Keller (1993) pointed out that consumers would evaluate the characteristics of various brands on the market before they make a choice, and the positive or negative evaluation of each brand can be called the brand attitude of the decision-makers. Therefore, as consumers' attitude can be used to predict consumers' purchase intention and related behaviors towards a brand, attitude has great impact on the brand, (Chaudhuri, 1999), and affects the overall value of the brand.

"Attitude" was originally a term used in psychology, and refers to an individual's overall evaluation of something (Allport, 1935). In other words, if the concept of attitude is applied to brand strategy, consumers' overall evaluation of a brand can be called brand attitude (Wilkie, 1986). Mitchell and Olson (1981) indicated that consumers' brand attitude towards a brand is their comprehensive evaluation of the various attributes of the brand. Keller, on the other hand, believed that brand attitude is consumers' overall measurement of a brand and the basis of their subsequent behavior towards the brand (Keller, 1993).

In terms of brand attitude, the three-factor model of attitude, which includes cognition, affect, and behavior, as proposed by Rosenberg and Hovland (1960), is widely cited by scholars at present. Lutz et al. (1983) further divided brand attitude into the cognitive level (advertising, brand cognition), affective level (advertising, brand attitude), and behavioral tendency (purchase intention). Assael (1995) divided brand attitude into brand belief, brand evaluation, and purchase intention, and believed that after consumers receive brand stimulation, there will be three different attitude components, which further affect brand attitude. These three attitude components usually influence each other, which means that when one attitude component changes, the other two attitude components usually change as well. Therefore, the purpose of many marketing strategies is to provide some incentives to change an attitude component, and then, indirectly affect consumer behavior.

Molenaar (2015) found that if a brand and Logo have high consistency, the Logo will affect consumers' positive attitude towards the brand, and make them feel that the Logo is appealing, beautiful, pleasant, and appropriate. In other words, if consumers believe that the Logo is appropriate to the meaning of the brand, they will have a more positive attitude towards the brand.

Peterson et al. (2015) discussed the relationship between Logo familiarity and brand attitude, and found that familiarity with the old Logo affected how consumers perceived the new Logo. In other words, the more familiar consumers are with a brand's old Logo, the more likely they will be able to perceive changes to the new Logo. This also shows that familiarity with a Logo helps to enhance consumers' interest in and positive attitude towards the brand.

Therefore, the hypotheses of this study are as follows:

H1a: Logo appropriateness has positive impact on brand attitude, that is, the higher the Logo appropriateness, the better the brand attitude.

H2a: Logo familiarity has positive impact on brand attitude, that is, the higher the Logo familiarity, the better the brand attitude.

\subsection{Brand Loyalty}

Brand loyalty, which has long been the core concept of brand marketing (Aaker, 1991), is a method to measure whether consumers are loyal to a brand, as the level of brand loyalty represents the possibility of customers purchasing other brands. The more loyal a consumer is to a brand, the less likely he or she is to be swayed by the lure of promotions or product upgrades from competitors. Conversely, consumers with low loyalty tend to purchase other brands.

Brand loyalty has considerable impact on marketing costs (Aaker, 1995). First, the cost of retaining existing customers is much lower than the cost of attracting new customers (Blackwell et al., 2006). Moreover, high loyalty also represents a significant barrier to entry for competitors, since the cost of enticing highly loyal consumers to buy other brands is often highly prohibitive. Fornell and Wernerfelt (1988) found that the cost of developing new customers is about three times that of maintaining current customers. Reichheld and Teal (2001) also found that every 5\% increase in customer loyalty can increase the company's profit 
rate by $40 \%$ to $95 \%$. In addition to proposing that customer loyalty has substantial cash value benefits, Reichheld and Sasser (1990) posited that if "customer retention" increases from $90 \%$ to $95 \%$, that is, if $5 \%$ of customers are retained for one more year, its annual total profit will increase by $75 \%$ on average. It can be seen that loyalty is key to corporate profits and one of the important goals for enterprises to improve. The better a brand can inspire consumer loyalty, the greater its potential for long-term success (Lindstrom, 2005).

At present, only the research of Müller et al. (2013) has explored the relationship between Logo appropriateness and brand loyalty. They argued that Logo appropriateness and Logo familiarity are correlated with brand loyalty after the intermediary of Logo attitude, brand attitude, and brand modernity.

Therefore, the hypotheses are as follows:

H1b: Logo appropriateness has positive impact on brand loyalty, that is, the higher the Logo appropriateness, the higher the brand loyalty.

H2b: Logo familiarity has positive impact on brand loyalty, that is, the higher the Logo familiarity, the higher the brand loyalty.

\subsection{The Interactive Effect of Logo Appropriateness and Logo Familiarity}

There are no discussions regarding the impacts of Logo appropriateness and Logo familiarity on consumers in existing research literature, and the only study that involves this issue is the study of Foroudi et al. (2014). According to their study, Logo design has impact on the brand image after being mediated by familiarity. Since both Logo appropriateness and Logo familiarity are closely related to Logo design, the following hypotheses are proposed in this study:

H3a: The higher the Logo appropriateness and familiarity, the better the brand attitude.

H3b: The higher the Logo appropriateness and familiarity, the better the brand loyalty.

\section{METHODS}

\subsection{Research Framework}

This study takes rebranding as the theme to explore the impact of Logo change on consumers. According to the literature review, it can be concluded that the level of Logo appropriateness and Logo familiarity have positive impact on brand attitude, brand loyalty, and consumers, respectively $(\mathrm{H} 1, \mathrm{H} 2)$. It is also expected that these two independent variables will influence each other, and then, the corresponding variables (H3). Based on the above three groups of hypotheses, this study draws the following conceptual framework (Figure 1).

Figure 1: Conceptual Framework

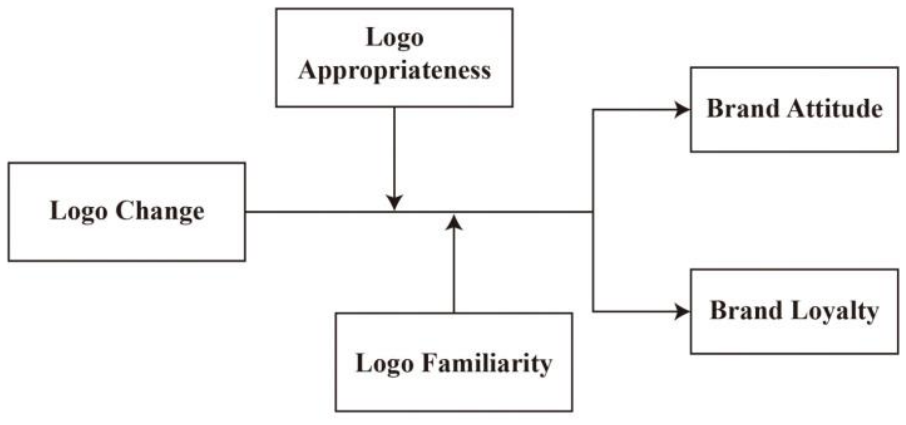

\subsection{Research Design}

As this study focuses on the discussion of Logo change, the experiment presents both the old and new Logos. Logo evaluation includes 4 groups of experimental situations: Logo appropriateness: high appropriateness vs. low appropriateness; Logo familiarity: high familiarity vs. low familiarity, which are factorial between-subjects design. All logos are presented in the form and color of the official website of the brand, and are tested in a similar size to ensure the consistency of the Logo. 


\subsection{Research Material}

To select a logo that conforms to the definition of design change, and considering the integrity of the data obtained from Logo change, this study selected 120 brand logos that have undergone rebranding and Logo change from the top 100 brands of "Best Global Brands 2018 (https://www.interbrand.com/best-brands/best-global-brands/2018)", as published by Interbrand, a brand consulting company, and the "Top 100 Most Valuable Global Brand 2019(http://bit.ly/GlobalDL2019)", as published by BrandZ, a brand research institution. In addition, 10 designers were invited to help classify the 120 logos into four groups, namely, high appropriateness -- high familiarity, high appropriateness -- low familiarity, low appropriateness -- high familiarity, and low appropriateness -- low familiarity. The experts were asked to pick out the most representative brand logos in each group from the four groups and set the experimental situation, as shown in Table 1.

Table 1: Independent Variable Manipulation-Four Groups of Logo Evaluation

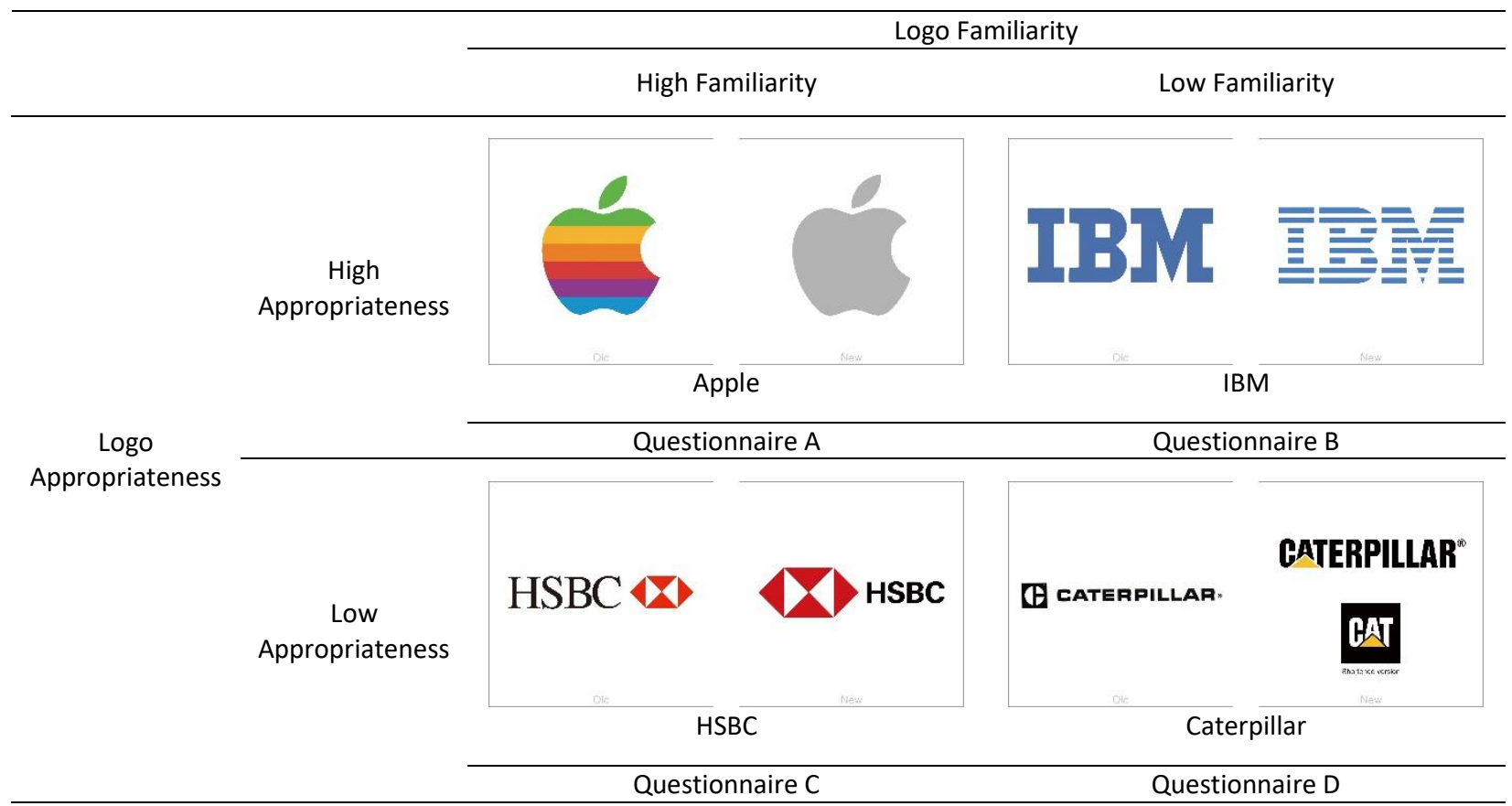

\subsection{Operational Definition and Measurement of Research Variables}

This study used the experimental design to test the hypotheses and observe the causal relationship between independent variables and dependent variables. The independent variables are Logo appropriateness (high appropriateness vs. low appropriateness), and Logo familiarity (high familiarity vs. low familiarity), and each has two levels, thus, this experiment is a $2 \times 2$ two-factor design. The operation definition, manipulation, and measurement of each variable in the experiment are described below.

\subsubsection{Logo Appropriateness}

According to previous literature, no scholars have studied and defined Logo appropriateness. Therefore, this study referred to the viewpoints of Doyle and Bottomley (2004) regarding different font appropriateness for brand names, and the operation of setting Logo appropriateness is defined as "whether the Logo appropriately represents the brand image".

In terms of the measurement of variables, this study referred to the dimension used in Bottomley and Doyle (2006), and divided Logo appropriateness into two levels: high appropriateness and low appropriateness. Based on this definition, this study developed a two-item measurement set (Table 2), as based on scales proposed by previous scholars, and used a Likert five-point scale for measurement ranging from 1 (strongly disagree) to 5 (strongly agree). A higher score indicates that the consumer thinks this Logo is more appropriate for the brand. 


\subsubsection{Logo Familiarity}

As no scholars have put forward a clear definition of Logo familiarity in the past, this study referred to the views of Alba and Hutchinson (1987) regarding brand familiarity, and defined Logo familiarity as "the degree of experience accumulated in consumers' memory through contact with a Logo".

In terms of the measurement of variables, this study referred to the dimension used in Campbell and Keller (2003), and divided Logo familiarity into two levels: high familiarity and low familiarity. Based on this definition, this study developed a two-item measurement set (Table 2), as based on scales proposed by previous scholars, and used a Likert five-point scale for measurement ranging from 1 (strongly disagree) to 5 (strongly agree). A higher score indicates that consumers are more familiar with the Logo.

\subsubsection{Brand Attitude}

Although different scholars have different definitions of brand attitude, most scholars agree that it is composed of three aspects: cognition, affect, and behavior (Breckler, 1984). Therefore, after referring to the scale proposed by previous scholars, and according to its practicability and validity, this study modified the measurement questions of cost research, which consists of three groups of questions (Table 2). A Likert 5-point scale was used in the measurement ranging from 1 (strongly disagree) to 5 (strongly agree).

\subsubsection{Brand Loyalty}

Hollis and Farr (1997) believed that the measurement of brand loyalty should include attitudinal loyalty and behavioral loyalty. The so-called behavioral loyalty refers to consumers' belief that a brand can provide some unique value (Oliver, 2014), while behavioral loyalty refers to customers' repeated and consistent purchase behavior for a brand (Chaudhuri and Holbrook, 2001). Based on the above definition and the scales developed by previous scholars, a three-question measurement set (Table 2) was proposed, and a Likert five-point scale was used for measurement ranging from 1 (strongly disagree) to 5 (strongly agree). After viewing the Logo, participants were asked to answer the questions.

Table 2: Operational Definitions, Measurement Questions, and Reference Sources of Variables

\begin{tabular}{|c|c|c|c|}
\hline Dimensions & Operational definitions & Measurement questions & References \\
\hline \multicolumn{4}{|l|}{ Logo Appropriateness } \\
\hline $\begin{array}{l}\text { Functional } \\
\text { Sensory-social }\end{array}$ & $\begin{array}{l}\text { Whether the Logo } \\
\text { appropriately represents the } \\
\text { brand image }\end{array}$ & $\begin{array}{l}\text { The new logo is more suitable for } \\
\text { [brand name] than the old one. } \\
\text { In general, the brand image of } \\
\text { [brand name] is highly suitable for } \\
\text { its logo design. }\end{array}$ & $\begin{array}{l}\text { Doyle and Bottomley, } 2004 \\
\text { Bottomley and Doyle, } 2006\end{array}$ \\
\hline \multicolumn{4}{|l|}{ Logo Familiarity } \\
\hline $\begin{array}{l}\text { Subjective familiarity } \\
\text { Objective familiarity }\end{array}$ & $\begin{array}{l}\text { The degree of contact with a } \\
\text { logo accumulated in the } \\
\text { consumer's memory }\end{array}$ & $\begin{array}{l}\text { I'm familiar with both the old and } \\
\text { new logos of [brand name]. } \\
\text { I know the new logo of [brand } \\
\text { name]. }\end{array}$ & $\begin{array}{l}\text { Hem and Iversen, } 2004 \\
\text { Foroudi et al., } 2014 \\
\text { Hirschman, } 1986\end{array}$ \\
\hline \multicolumn{4}{|l|}{ Brand Attitude } \\
\hline Cognitive & & $\begin{array}{l}\text { The new logo makes me feel that } \\
\text { the quality of [brand name] is } \\
\text { good. }\end{array}$ & Burton et al., 1998 \\
\hline Affective & $\begin{array}{l}\text { Consumers' overall } \\
\text { evaluation of the brand }\end{array}$ & $\begin{array}{l}\text { The new Logo makes me feel good } \\
\text { about buying [brand name] } \\
\text { products. }\end{array}$ & Burton et al., 1998 \\
\hline Behavioral & & $\begin{array}{l}\text { The new logo makes me feel that } \\
\text { choosing [brand name] is a wise } \\
\text { decision. }\end{array}$ & Beatty and Kahle, 1988 \\
\hline \multicolumn{4}{|l|}{ Brand Loyalty } \\
\hline Attitudinal loyalty & & $\begin{array}{l}\text { The new logo makes me more } \\
\text { loyal to [brand name]. }\end{array}$ & Yoo et al., 2000 \\
\hline
\end{tabular}


Consumers believe that brands can provide some unique value Consumers' behavior for Behavioral loyalty repeated purchase of the brand
The new logo makes me more willing to choose [brand name].

Zeithaml et al., 1996

During my next purchase, I will buy the products with [brand name] new logo.

\section{FINDINGS AND DISCUSSIONS}

\subsection{Sample Structure Analysis}

This study has 4 groups of situational questionnaires, which were distributed from May 12, 2020 to June 24, 2020. There were 115 questionnaires for each group, a total of 460 questionnaires were sent out, and 460 were successfully recovered. After removing 20 questionnaires with incomplete answers or too many omissions, a total of 440 samples were included in effective analysis, for an effective sample rate of $95.65 \%$.

Among the subjects, there were 149 males and 291 females, and most were under 20 years old, accounting for $51.8 \%$. Most of them majored in business management or design art, both of which were 182 , accounting for $41.4 \%$. The majority subjects had a monthly disposable income of NTD 5,000 to 10,000, accounting for $45.5 \%$.

\subsection{Manipulation Test}

Before hypothesis testing, reliability and validity analysis and manipulation testing of the questionnaire were carried out to confirm the applicability of the questionnaire, and that the collected data were sufficient to reflect the actual phenomenon.

\subsubsection{Reliability}

This study used a set of two to three items to measure the opinions of participants with four variables. In order to ensure the consistency of the measured results, Cronbach's $\alpha$ coefficient, which is commonly used in behavioral science, was used as a reliability analysis tool to confirm that each measurement variable was highly reliable and included the same dimension.

According to reliability analysis, Logo Appropriateness $\alpha=.812$, Logo personality $\alpha=.871$, Brand Attitude $\alpha=.859$, Brand Loyalty $\alpha$ $=.701$. The values of Cronbach's $\alpha$ are all greater than 0.7 , indicating that the items in each group have high reliability. The reliability of items in each variable group is shown in Table 3.

Table 3: Reliability Analysis Results

\begin{tabular}{lcc}
\hline Variable & Number of items & Cronbach's Alpha \\
\hline Logo Appropriateness & 2 & .812 \\
Logo Familiarity & 2 & .871 \\
Brand Attitude & 3 & .859 \\
Brand Loyalty & 3 & .701 \\
\hline
\end{tabular}

\subsubsection{Validity}

In order to confirm the accuracy of the assessment tool (questionnaire) and the assessment procedures in the measurement of the research variables, qualitative assessment (content validity) and empirical testing (construct validity) were used for testing.

(1) Content validity

This study used a set of two to three items to measure the opinions of participants with four variables. In terms of validity, the items and dimensions of the questionnaire were designed by referring to previous literature, and were revised based on logical reasoning and expert suggestions. Before the formal questionnaire was sent out, the results of the pre-test questionnaire were used to examine the fitness of the items in each dimension; therefore, the questionnaire has high expert validity and face validity. 


\section{(2) Construct validity}

As there are ten items and four types in this research, principal component analysis in factor analysis and the varimax method were used to conduct factor analysis on the four designated factors in the empirical test. Analysis results found that the factor loadings of each item were all above .5 , and they were all classified into a single factor, which accurately corresponds to the original questionnaire set items, and indicates that all the items in this study had convergent validity and discriminant validity. In addition, after further observation of the factor loadings of the four factors, it was found that the cumulative explanatory variation was $89.448 \%$, which indicates that the meaning represented by each factor could be effectively explained; therefore, the questionnaire in this study has construct validity.

\subsection{Hypotheses Testing}

The hypotheses to be verified were divided into two parts. The first part included the multivariate analysis and the homogeneity test of variance, which were used to preliminarily confirm whether the main effects and interactions were established, in order to prepare for more detailed analysis.

Then, $\mathrm{H} 1$ and $\mathrm{H} 2$ were tested to analyze the main effects of each variable (Logo appropriateness and Logo familiarity) on each dependent variable (brand attitude and brand loyalty).

The second part included the verification of $\mathrm{H} 3$, which mainly focused on the influence of the interaction between Logo appropriateness and Logo familiarity on the dependent variables.

\subsubsection{ANOVA}

Multivariate tests indicate whether the variables differ significantly for a linear combination of multiple dependent variables in statistics. In addition, ANOVA has several basic hypotheses that must be met before analysis can be carried out, in order that the results will not be erroneous (Stone and Hollenbeck, 1989). Therefore, the test of homogeneity of variance was carried out first, and then, the multivariate statistical results were analyzed.

(1) Test of Homogeneity of variance

First, Levene's test was used to conduct the Test of Homogeneity of variance to observe the homogeneity of variance of each group.

The results show that the significance of brand attitude was $\mathrm{P}=.559$ and brand loyalty was $\mathrm{P}=.775$, both of which reach the significant level $(P>0$. 05). Therefore, there was no significant difference between the two groups, indicating high homogeneity.

(2) Analysis of main results

The main effect analysis was conducted by using MANOVA: 2 (Logo Appropriateness: high appropriateness vs. low appropriateness) $\times 2$ (Logo Familiarity: high familiarity vs. low familiarity), and the verification results are shown in Table 3 .

Table 4: MANOVA Results

\begin{tabular}{lccccc}
\hline \multirow{2}{*}{ Source } & \multirow{2}{*}{ df } & \multicolumn{2}{c}{ Brand Attitude } & \multicolumn{2}{c}{ Brand Loyalty } \\
\cline { 3 - 6 } & & MS & F value & MS & F value \\
\hline Logo Appropriateness & 1 & 5.991 & $17.650^{* * *}$ & 10.897 & $20.111^{* * *}$ \\
Logo Familiarity & 1 & 1.541 & $4.540^{*}$ & 3.039 & $5.609^{*}$ \\
Logo Appropriateness*Logo Familiarity & 1 & 1.488 & $4.383^{*}$ & 8.984 & $16.582^{* * *}$ \\
\hline
\end{tabular}

Note: ${ }^{*} \mathrm{P}<0.05,{ }^{*} \mathrm{P}<0.01,{ }^{* * *} \mathrm{P}<0.001$

In terms of brand attitude, Logo Appropriateness ( $\mathrm{F}=17.650, \mathrm{P}<0.001)$ and Logo Familiarity $(\mathrm{F}=4.540, \mathrm{P}=.034)$ have significant difference. In terms of brand loyalty, Logo Appropriateness ( $F=20.111, P<0.001)$ and Logo Familiarity $(F=5.609, P=.018)$ also have significant difference, which indicates that this data can be analyzed in depth. 
(3) The main effect of Logo appropriateness

$\mathrm{H} 1$ is used to explore the main effect of Logo appropriateness. As can be seen from the MANOVA results in Table 4, Logo appropriateness has significant differences in brand attitude and brand loyalty $\left(F_{\text {Brand Attitude }}=17.650, P<0.01 ; F_{\text {Brand Loyalty }}=20.111\right.$, $\mathrm{P}<0.01$ ). Table 5 shows the mean and standard deviation of different Logo appropriateness on the two variables.

Table 5: The Mean and Standard Deviation of Different Logo Appropriateness on Two Variables

\begin{tabular}{cccccc}
\hline \multirow{2}{*}{ Logo Appropriateness } & \multirow{2}{*}{$\mathbf{N}$} & \multicolumn{2}{c}{ Brand Attitude } & \multicolumn{2}{c}{ Brand Loyalty } \\
\cline { 3 - 6 } & & Mean & SD & Mean & SD \\
\hline High appropriateness & 220 & 3.608 & .764 & 3.557 & .979 \\
Low appropriateness & 220 & 3.339 & .813 & 3.210 & .826 \\
\hline
\end{tabular}

In terms of brand attitude, the mean of high appropriateness was 3.608 (SD=.764), which is higher than the mean of low appropriateness at $3.339(\mathrm{SD}=.813$ ). Therefore, $\mathrm{H} 1 \mathrm{a}$ (Logo appropriateness has positive impact on brand attitude, that is, the higher the Logo appropriateness, the better the brand attitude.) is supported.

In terms of brand loyalty, the mean of high appropriateness was 3.557 (SD=.979), which is higher than the mean of low appropriateness at 3.210 ( $\mathrm{SD}=.826$ ), which is consistent with $\mathrm{H} 1 \mathrm{~b}$ (Logo appropriateness has positive impact on brand loyalty, that is, the higher the Logo appropriateness, the higher the brand loyalty.), thus, $\mathrm{H} 1 \mathrm{~b}$ is established.

(4) The main effect of Logo familiarity

$\mathrm{H} 2$ was used to explore the main effect of Logo familiarity. As can be seen from the MANOVA results in Table 4, Logo familiarity has significant differences in brand attitude and brand loyalty ( $F$ Brand Attitude $=4.540, P<0.05 ; F$ Brand Loyalty $=5.609, P<0.05$ ). Table 6 shows the mean and standard deviation of different Logo familiarity on the two variables.

Table 6: The Mean and Standard Deviation of Different Logo Familiarity on Two Variables

\begin{tabular}{cccccc}
\hline \multirow{2}{*}{ Logo Familiarity } & \multirow{N}{*}{} & \multicolumn{2}{c}{ Brand Attitude } & \multicolumn{2}{c}{ Brand Loyalty } \\
\cline { 3 - 6 } & & Mean & SD & Mean & SD \\
\hline High familiarity & 220 & 3.559 & .781 & 3.491 & 1.004 \\
Low familiarity & 220 & 3.388 & .810 & 3.276 & .816 \\
\hline
\end{tabular}

In terms of brand attitude, the mean of high familiarity was 3.559 (SD=.781), which is higher than the mean of low familiarity at $3.388(\mathrm{SD}=.810$ ), which is consistent with $\mathrm{H} 2$ a (Logo familiarity has positive impact on the brand attitude, that is, the higher the Logo familiarity, the better the brand attitude.), thus, $\mathrm{H} 2 \mathrm{a}$ is established.

In terms of brand loyalty, the mean of high familiarity was 3.491 (SD=1.004), which is higher than the mean of low familiarity at 3.276 (SD=.816). Therefore, $\mathrm{H} 2 \mathrm{~b}$ (Logo familiarity has positive impact on brand loyalty, that is, the higher the Logo familiarity, the higher the brand loyalty.) is supported.

\subsubsection{The Interactive Effect of Logo Appropriateness and Logo Familiarity}

$\mathrm{H} 3$ explores the influence of the interaction between Logo appropriateness and Logo familiarity, and aims to observe the influence of different Logo appropriateness on consumers' familiarity with the Logo. As can be seen from the Table 4, the interaction between Logo appropriateness and Logo familiarity has significant differences in brand attitude and brand loyalty ( $F$ Brand Attitude $=4.383, \mathrm{P}<0.05 ; \mathrm{F}_{\text {Brand Loyalty }}=16.582, \mathrm{P}<0.001$ ). The interaction between Logo familiarity and Logo appropriateness on brand attitude can be seen in Figure 2, while their interaction on brand loyalty can be seen in Figure 3 . Table 7 shows the means and standard deviations of various combinations of logo appropriateness and logo familiarity on the two dependent variables. 
Table 7: Mean and Standard Deviation of Various Combinations of Logo Appropriateness and Logo Familiarity on The Dependent Variables

\begin{tabular}{cllllll}
\hline \multirow{2}{*}{ Logo Appropriateness } & Logo Familiarity & \multirow{N}{*}{} & \multicolumn{2}{c}{ Brand Attitude } & \multicolumn{2}{c}{ Brand Loyalty } \\
\cline { 5 - 8 } & & & Mean & SD & Mean & SD \\
\hline \multirow{2}{*}{ High appropriateness } & High familiarity & 110 & 3.756 & .715 & 3.810 & 1.083 \\
& Low familiarity & 110 & 3.461 & .786 & 3.303 & .788 \\
\multirow{2}{*}{ Low appropriateness } & High familiarity & 110 & 3.362 & .798 & 3.173 & .806 \\
& Low familiarity & 110 & 3.315 & .831 & 3.249 & .847 \\
\hline
\end{tabular}

In terms of brand attitude, when the brand Logo was highly appropriate, the mean of high familiarity was 3.756 (SD=.715), while the mean of low familiarity was $3.461(\mathrm{SD}=.786)$. It can be seen that the mean of high Logo familiarity is significantly higher than that of low Logo familiarity, thus, H3a (The higher the Logo appropriateness and familiarity, the better the brand attitude.) is supported.

Similarly, in terms of brand loyalty, when the brand Logo was highly appropriate, the mean of high familiarity $(M=3.810$, $\mathrm{SD}=1.083$ ) was higher than that of low familiarity $(\mathrm{M}=3.303, \mathrm{SD}=.788$ ) which is consistent with $\mathrm{H} 3 \mathrm{~b}$ (The higher the Logo appropriateness and familiarity, the better the brand loyalty.). Therefore, $\mathrm{H} 3 \mathrm{~b}$ is supported.

Figure 2: The Interaction of Logo Familiarity and Logo Appropriateness in Brand Attitude

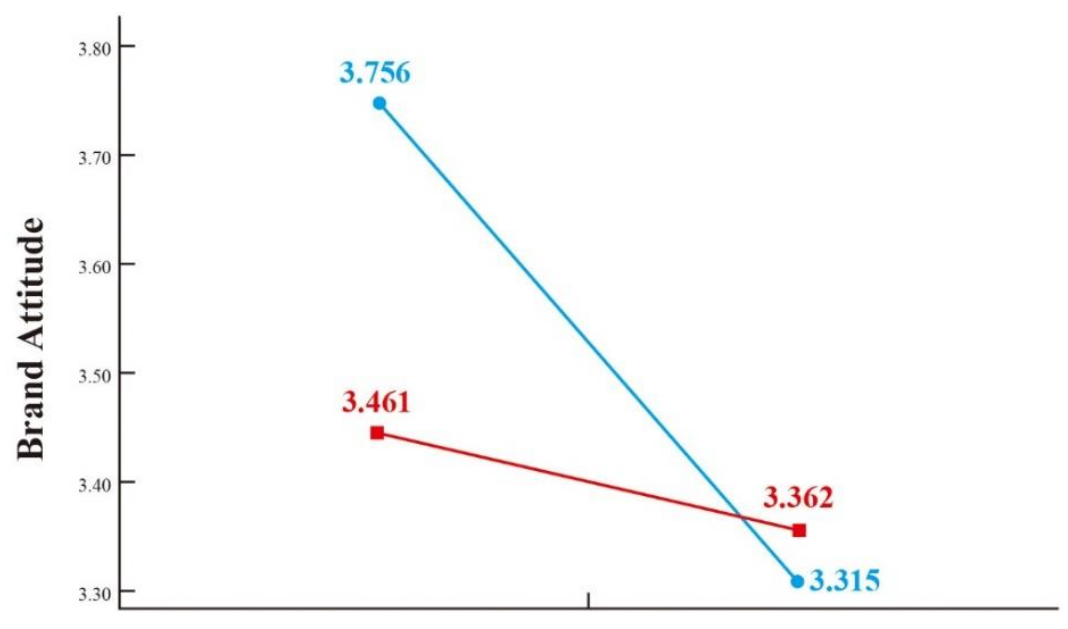

High Appropriateness $\quad$ Low Appropriateness

\section{Logo Appropriateness}

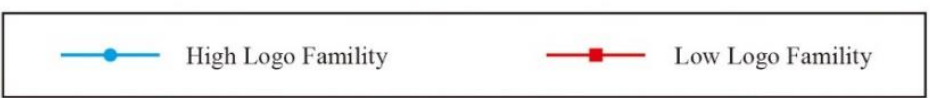


Figure 3: The Interaction of Logo Familiarity and Logo Appropriateness in Brand Loyalty

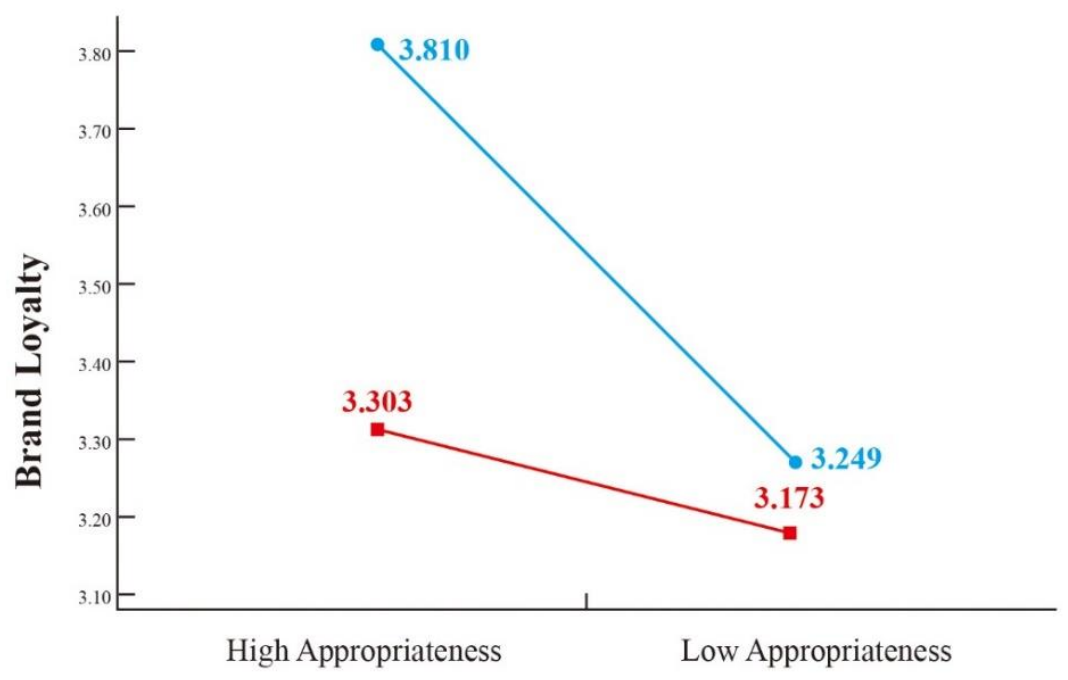

Logo Appropriateness

$$
\longrightarrow \text { High Logo Famility } \longrightarrow \text { Low Logo Famility }
$$

\subsection{Summary of Results}

The main purpose of this study was to explore the influence of Logo appropriateness and Logo familiarity on brand attitude and brand loyalty. This section tests and verifies the hypotheses derived in this study through data analysis, and the research results are shown in Table 8.

\section{Table 8: Table of Hypothesis Testing}

\begin{tabular}{|c|c|c|}
\hline Hypothesis & Hypothesis content & Results \\
\hline $\mathrm{H} 1 \mathrm{a}$ & $\begin{array}{l}\text { Logo appropriateness has positive impact on brand attitude, that is, the higher the } \\
\text { Logo appropriateness, the better the brand attitude. }\end{array}$ & Supported \\
\hline $\mathrm{H} 1 \mathrm{~b}$ & $\begin{array}{l}\text { Logo appropriateness has positive impact on brand loyalty, that is, the higher the Logo } \\
\text { appropriateness, the higher the brand loyalty. }\end{array}$ & Supported \\
\hline $\mathrm{H} 2 \mathrm{a}$ & $\begin{array}{l}\text { Logo familiarity has positive impact on the brand attitude, that is, the higher the Logo } \\
\text { familiarity, the better the brand attitude. }\end{array}$ & Supported \\
\hline $\mathrm{H} 2 \mathrm{~b}$ & $\begin{array}{l}\text { Logo familiarity has positive impact on brand loyalty, that is, the higher the Logo } \\
\text { familiarity, the higher the brand loyalty. }\end{array}$ & Supported \\
\hline $\mathrm{H} 3 \mathrm{a}$ & The higher the Logo appropriateness and familiarity, the better the brand attitude. & Supported \\
\hline $\mathrm{H} 3 \mathrm{~b}$ & The higher the Logo appropriateness and familiarity, the better the brand loyalty. & Supported \\
\hline
\end{tabular}

According to Table 8, all three hypotheses are supported.

\subsection{Discussions and Research Findings}

Three groups of hypotheses were proposed in this study. The causal relationship between the two independent variables (Logo appropriateness and Logo familiarity) and the two dependent variables (brand attitude and brand loyalty) was investigated through the first and second hypotheses groups. The third group of hypotheses explored the influence of the interaction of two independent variables on the dependent variable. The descriptions are, as follows: 


\section{Logo appropriateness has a positive effect on brand attitude and brand loyalty.}

The first group of hypotheses discuss the effect of Logo appropriateness on the dependent variables, and the results show that Logo appropriateness has positive impact on both brand attitude $(\mathrm{H} 1 \mathrm{a})$ and brand loyalty $(\mathrm{H} 1 \mathrm{~b})$.

Molenaar (2015) found that consumers would have a more positive attitude towards a brand if there is high consistency between the brand and the Logo, which is consistent with the results of this study (H1a). In other words, consumers will have a more positive attitude towards a brand if they think the Logo is appropriate to the brand.

However, the conclusions of another study that discussed Logo appropriateness are not completely consistent with this study. Muller et al. (2013) hypothesized that Logo appropriateness would further influence brand attitude and brand loyalty after being mediated by Logo attitude. Although the research results confirmed that brand attitude has significant impact on brand loyalty, it also found that Logo appropriateness has no significant impact on Logo attitude. While their study did not explain the possible reasons for the insignificant relationship between the two variables, the conclusion of this study may provide a more reasonable explanation, namely, the impact of Logo appropriateness on consumers may be directly reflected in consumers' attitudes towards the brand, without the mediation of Logo attitude.

At present, only Müller et al. (2013) have studied the relationship between logo appropriateness and brand loyalty (H1b). In their research, Logo appropriateness was only related to brand loyalty through Logo attitude, brand attitude, and brand modernity; however, they found that Logo appropriateness was not significantly associated with Logo attitudes. In other words, Logo appropriateness was not strongly associated with brand loyalty in their study, which is contrary to the findings of this study.

While their study offered no further explanation for the insignificant correlation between Logo appropriateness and Logo attitude, this study confirms that Logo appropriateness has a direct cause-and-effect relationship with brand loyalty. This conclusion may provide a more reasonable explanation for their study results.

Although this study only hypothesizes logos with high appropriateness, the research results confirm that when Logo appropriateness is low, brand attitude and brand loyalty will decrease. Such results also represent that consumers' perception of Logo appropriateness is comprehensive and directly affects their consumption behavior.

Logo familiarity has a positive effect on brand attitude and brand loyalty.

The second group of hypotheses focused on the corollary of the effect of Logo familiarity on the dependent variables. The results show that Logo familiarity has positive impact on brand attitude $(\mathrm{H} 2 \mathrm{a})$, which indicates that if consumers are familiar with the brand Logo, they will also have a more positive attitude towards the brand. This result is consistent with the research conclusion of Peterson et al. (2015), which found that familiarity with the old Logo affected how consumers perceived the new Logo and how consumers felt about the brand. That is, the more familiar a consumer is with the brand's past Logo, the more likely he or she will be able to detect changes to the new Logo, and such awareness will help to increase consumers' interest and positive attitude towards brands.

Müller et al. (2013) mentioned that consumers' level of brand loyalty is affected by their familiarity with the Logo, which is similar to the research results obtained in this study $(\mathrm{H} 2 \mathrm{~b})$. However, in their research, Logo familiarity did not have direct impact on brand loyalty, meaning brand loyalty is only impacted by the intermediary effects of Logo attitude, brand attitude, and brand modernity. Thus, the conclusions of this study further identify the causal relationship between Logo familiarity and brand loyalty, and extend and supplement the views of Müller et al. (2013).

The interaction between logo appropriateness and logo familiarity has positive impact on brand attitude and brand loyalty.

The third group of hypotheses analyzed the interaction between Logo appropriateness and Logo familiarity, and the results show that the interaction between the two variables has positive effect on brand attitude (H3a) and brand loyalty (H3b).

With the exception of the study by Foroudi et al. (2014), previous studies failed to explore the impact of Logo appropriateness and Logo familiarity on consumers. However, their research mainly discussed the impact of Logo design on brand image, and familiarity was only one of the mediating variables. This study further identified a closer link between Logo design appropriateness and Logo familiarity, which is supported by the statistical results. As the results of this study extend the impact of Logo appropriateness and familiarity on consumers to include brand attitude and brand loyalty, it further extends their research thesis. 


\section{CONCLUSION}

The results show that appropriate Logo design and Logo familiarity can effectively improve consumers' brand attitude and brand loyalty. An important factor in whether a Logo is appropriate, and whether consumers are familiar with it, is the visual presentation of the Logo. In other words, if the Logo design is not appropriate and familiarity is too low, it will probably receive a lot of negative feedback from consumers, which will result in a worse relationship between the brand and consumers.

In addition, the research results show that if a brand Logo has an appropriate design, and it is able to maintain a high degree of familiarity, the desired effect can be achieved, which also demonstrates the importance of Logo design in this issue. Therefore, in order to create the ideal Logo design before implementing a Logo change project, Logo designers must have a deep understanding of the core concept of the brand.

\subsection{Managerial Implications}

The conclusion of this study confirms that Logo design can affect consumer behavior, such as brand attitude and brand loyalty. Therefore, this study suggests that, when brand managers change their Logo, they should pay more attention to consumers' opinions, and integrate internal opinions. Brand managers should carefully carry out the planning and implementation of a rebranding strategy based on the current situation of the brand's image.

In the implementation of Logo change projects, this study suggests that progress management and evaluations should be carried out in three stages: before, during, and after the change.

Before the change: there is often a gap between the brand manager's definition of the brand core, designer's visual interpretation of the concept, and consumer's interpretation of logo meaning, thus, they should repeatedly review the change options. Before a Logo change, brand managers and Logo designers should conduct an extensive and objective survey on consumers and the market, truly understand the market demand and consumer attitude, and then, define the target strategy of the Logo change according to the core value of the brand.

During the change: Logo designers and brand managers should work closely and pay attention to the link between the original logo's symbolic value and the brand's core statement at all times. Whether the strategy chosen is revolutionary or incremental, the design of the new Logo should focus on symbolic meaning, familiarity, and appropriateness.

After the change: after a Logo change, it is unlikely that the market will immediately have a positive attitude towards the new Logo and brand (Molenaar, 2015). As even Starbucks, Pepsi, and other international brands have encountered many objections in the early stage of a logo change, brand managers should continue to interact and communicate with consumers after the Logo change, track the reaction of consumers and the market, and make real-time strategic adjustments according to market changes. Therefore, keeping abreast of market dynamics and communicating with consumers are important factors for the success of a Logo change.

\subsection{Limitations and Future Research}

As mentioned in the literature review, "rebranding" is a very important issue in brand management, and a Logo change is only one part of the rebranding strategy. In other words, whether a changed Logo can be successful requires the support of follow-up brand management and marketing activities. Although this study discussed Logo changes, there are still many aspects worthy of further exploration.

First, the logos that met the needs of this study were selected from the world's top 100 famous brands for the experiment, and although this approach has its universality, it ignores the uniqueness of each industry in brand management. Future researchers can refer to the framework of this study and discuss and observe Logo changes according to industry categories, such as food, electronics, and financial industries.

In addition, while there are many factors that affect the visual elements of a logo, such as brand name, symbol, and color, this study did not discuss all the factors. The reason is that the focus of this study was to evaluate the impact of a Logo on consumer behavior in a comprehensive manner, rather than the impact of a single element. However, that does not mean that changes in a single element are not important to consumers. In fact, consumers have unique ideas regarding the use of brand colors, fonts, and symbols, thus, they will "make clear judgments about the image of a firm from the Logo design and have strong opinions about which colors are appropriate for different corporate images" (Hynes, 2009, p. 545). Moreover, many studies have proved that Logo design, font, color, and other elements can affect consumers' attitude towards enterprises, and even corporate 
reputation (Foroudi et al., 2014); therefore, it is suggested that future researchers can refer to the conclusions of this study to further discuss the visual elements of a Logo. If they can identify which element or combination of elements has the greatest impact on consumer behavior, they will be able to provide brand managers with more accurate suggestions for Logo changes.

\section{REFERENCES}

Aaker, D. A. (1991). Managing brand equity: Capitalizing on the value of a brand name. New York, NY: Free Press.

Aaker, D. A. (1995). Strategic market management (4th ed.). New York: Wiley.

Aaker, D. A. (2004). Leveraging the Corporate Brand. California Management Review, 46(3), 6-18. DOI:10.2307/41166218

Adams, S. (2008). Masters of design: Logos and identity: Learn from twenty designers who have changed the logo landscape. Beverly, MA: Pockport.

Alba, J. W., and Hutchinson, J. W. (1987). Dimensions of Consumer Expertise. Journal of Consumer Research, 13(4), 411-454. DOI:10.1086/209080

Allport, G. W. (1935). Attitudes. In C. Murchison (Ed.), Handbook of social psychology (pp. 798-844). Worcester, MA: Clark University Press

Assael, H. (1995). Consumer behavior and marketing action (5th ed.). Cincinnati, OH: South-Western.

Banerjee, S. (2008). Logo Change: Little Image Touch up or Serious Overhaul! Imperatives and Scanning Parameters. Journal of Marketing \& Communication, 4(1), 59-70.

Beatty, S. E., and Kahle, L. R. (1988). Alternative hierarchies of the attitude-behavior relationship: The impact of brand commitment and habit. Journal of the Academy of Marketing Science, 16(2), 1-10. DOI:10.1007/bf02723310

Bettman, J. R., and Sujan, M. (1987). Effects of Framing on Evaluation of Comparable and Noncomparable Alternatives by Expert and Novice Consumers. Journal of Consumer Research, 14(2), 141-154. DOI:10.1086/209102

Blackwell, R. D., Miniard, P. W., and Engel, J. F. (2006). Consumer behavior. Mason, OH: Thomson/South-Western.

Bolhuis, W., de Jong, M. D., and van den Bosch, A. L. (2018). Corporate rebranding: effects of corporate visual identity changes on employees and consumers. Journal of marketing communications, 24(1), 3-16.

Bottomley, P. A., and Doyle, J. R. (2006). The interactive effects of colors and products on perceptions of brand logo appropriateness. Marketing Theory, 6(1), 63-83. DOI:10.1177/1470593106061263

Breckler, S. J. (1984). Empirical validation of affect, behavior, and cognition as distinct components of attitude. Journal of Personality and Social Psychology, 47(6), 1191-1205. DOI:10.1037/0022-3514.47.6.1191

Burton, S., Lichtenstein, D. R., Netemeyer, R. G., and Garretson, J. A. (1998). A Scale for Measuring Attitude toward Private Label Products and an Examination of its Psychological and Behavioral Correlates. Journal of the Academy of Marketing Science, 26(4), 293-306. DOI:10.1177/0092070398264003

Campbell, M., and Keller, K. (2003). Brand Familiarity and Advertising Repetition Effects. Journal of Consumer Research, 30(2), $292-304$. DOI:10.1086/376800

Chadwick, S., and Walters, G. (2009). Sportswear identification, distinctive design and manufacturer logos - issues from the front line. The Marketing Review, 9(1), 63-78. DOI:10.1362/146934709x414332

Chaudhuri, A. (1999). Does Brand Loyalty Mediate Brand Equity Outcomes? Journal of Marketing Theory and Practice, 7(2), 136-146. DOI:10.1080/10696679.1999.11501835

Chaudhuri, A., and Holbrook, M. B. (2001). The Chain of Effects from Brand Trust and Brand Affect to Brand Performance: The Role of Brand Loyalty. Journal of Marketing, 65(2), 81-93. DOI:10.1509/jmkg.65.2.81.18255

DeVellis, R. F. (2017). Scale development: Theory and applications. Los Angeles: SAGE.

Doyle, J. R., and Bottomley, P. A. (2004). Font appropriateness and brand choice. Journal of Business Research, 57(8), 873-880. DOI:10.1016/s01482963(02)00487-3

Fazio, R. H. (1986). How do attitudes guide behavior? In R. M. Sorrentino and E. T. Higgins (Eds.), Handbook of motivation and cognition: Foundations of social behavior (pp. 204-243). New York: Guilford Press.

Fornell, C., and Wernerfelt, B. (1988). A Model for Customer Complaint Management. Marketing Science, 7(3), 287-298. DOI:10.1287/mksc.7.3.287

Foroudi, P., Melewar, T., and Gupta, S. (2014). Linking corporate logo, corporate image, and reputation: An examination of consumer perceptions in the financial setting. Journal of Business Research, 67(11), 2269-2281. DOI:10.1016/j.jbusres.2014.06.015 
Frascara, J. (1988). Graphic Design: Fine Art or Social Science? Design Issues, 5(1), 18-29. DOI:10.2307/1511556

Ghiselli, E. E., Campbell, J. P., and Zedeck, S. (1981). Measurement theory for the behavioral sciences. San Francisco: W.H. Freeman.

Haig, W. L., and Harper, L. (1997). Logo power: How to create effective company logos. New York, NY: John Wiley and Sons.

Haley, R. I., and Case, P. B. (1979). Testing Thirteen Attitude Scales for Agreement and Brand Discrimination. Journal of Marketing, 43(4), 20-32. DOI:10.1177/002224297904300403

Hawkins, D. I., Best, R. J., and Coney, K. A. (1998). Consumer behavior: Building market strategy (7th ed.). Boston, MA: McGraw-Hill.

Hem, L. E., and Iversen, N. M. (2004). How to Develop a Destination Brand Logo: A Qualitative and Quantitative Approach. Scandinavian Journal of Hospitality and Tourism, 4(2), 83-106. DOI:10.1080/15022250410003852

Henderson, P. W., Cote, J. A., Leong, S. M., and Schmitt, B. (2003). Building strong brands in Asia: Selecting the visual components of image to maximize brand strength. International Journal of Research in Marketing, 20(4), 297-313. DOI:10.1016/j.jiresmar.2003.03.001

Hirschman, E. C. (1986). The Effect of Verbal and Pictorial Advertising Stimuli on Aesthetic, Utilitarian and Familiarity Perceptions. Journal of Advertising, 15(2), 27-34. DOI:10.1080/00913367.1986.10673002

Hollis, N., and Farr, A. (1997). What do you want your brand to be when it grows up: Big and strong. Journal of Advertising research, 36(6), 23-36.

Hynes, N. (2009). Colour and meaning in corporate logos: An empirical study. Journal of Brand Management, 16(8), 545-555. DOI:10.1057/bm.2008.5

Kaikati, J. G., and Kaikati, A. M. (2004). Identity crisis: The dos and don'ts of brand rechristening. Marketing Management, 13(1), 45-49.

Kapferer, J. (2008). The new strategic brand management: Creating and sustaining brand equity long term (4th ed.). London: Kogan Page.

Keller, K. L. (1993). Conceptualizing, Measuring, and Managing Customer-Based Brand Equity. Journal of Marketing, 57(1), 1-22. DOI:10.1177/002224299305700101

Keller, K. L. (1998). Strategic Brand Management: Building, Measuring, and Managing Brand Equity. New Jersey, NJ: Pearson Education.

Keller, K. L. (1999). Managing Brands for the Long Run: Brand Reinforcement and Revitalization Strategies. California Management Review, 41(3), 102-124. DOI:10.2307/41165999

Keller, K. L. (2013). Strategic brand management: Building, measuring, and managing brand equity (4th ed.). Boston: Pearson.

Kent, R. J., and Allen, C. T. (1994). Competitive Interference Effects in Consumer Memory for Advertising: The Role of Brand Familiarity. Journal of Marketing, 58(3), 97-105. DOI:10.1177/002224299405800307

Kohli, C., and Suri, R. (2002). Creating effective logos: Insights from theory and practice. Business Horizons, 45(3), 58-64. DOI: 10.1016/s00076813(02)00203-3

Lehu, J. (2004). Back to life! Why brands grow old and sometimes die and what managers then do: An exploratory qualitative research put into the French context. Journal of Marketing Communications, 10(2), 133-152. DOI:10.1080/13527260410001693811

Lindstrom, M. (2005). Brand sense: How to build powerful brands through touch, taste, smell, sight and sound. London: Kogan Page.

Lutz, R.J., S.B. MacKenzie, and G.E. Belch (1983), Attitude toward the Ad as a Mediator of Advertising Effectiveness: Determinants and Consequences, Advances in Consumer Research, 10, 532-539.

Melewar, T., and Akel, S. (2005). The role of corporate identity in the higher education sector. Corporate Communications: An International Journal, 1O(1), 41-57. DOI: 10.1108/13563280510578196

Melewar, T., and Saunders, J. (1998). Global corporate visual identity systems. International Marketing Review, 15(4), $291-308$. DOI:10.1108/02651339810227560

Mitchell, A. A., and Olson, J. C. (1981). Are Product Attribute Beliefs the Only Mediator of Advertising Effects on Brand Attitude? Journal of Marketing Research, 18(3), 318-332. DOI:10.2307/3150973

Molenaar, J. (2015). Brand logo modifications: Adhering to traditionalism, or pursuing modernity? (Master's thesis, University of Twente). Retrieved from http://purl.utwente.nl/essays/67370

Müller, B., Kocher, B., and Crettaz, A. (2013). The effects of visual rejuvenation through brand logos. Journal of Business Research, 66(1), 82-88. DOI: 10.1016/j.jbusres.2011.07.026

Muzellec, L., and Lambkin, M. (2006). Corporate rebranding: Destroying, transferring or creating brand equity? European Journal of Marketing, 4O(7/8), 803-824. DOI:10.1108/03090560610670007 
Muzellec, L., Doogan, M., and Lambkin, M. (2003). Corporate rebranding-an exploratory review. Irish Marketing Review, 16, 31-40.

Odin, Y., Odin, N., and Valette-Florence, P. (2001). Conceptual and operational aspects of brand loyalty: An empirical investigation. Journal of Business Research, 53(2), 75-84. DOI:10.1016/s0148-2963(99)00076-4

Oliver, R. L. (2014). Satisfaction: A behavioral perspective on the consumer. London: Routledge.

Peterson, M., Alshebil, S., and Bishop, M. (2015). Cognitive and emotional processing of brand logo changes. Journal of Product \& Brand Management, 24(7), 745-757. DOI:10.1108/jpbm-03-2015-0823

Pimentel, R. W., and Heckler, S. E. (2003). Changes in logo designs: Chasing the elusive butterfly curve. Persuasive imagery: A consumer response perspective, 105-127.

Reichheld, F. F., and Teal, T. (2001). The loyalty effect: The hidden force behind growth, profits, and lasting value. Boston, MA: Harvard Business School.

Reichheld, F., and Sasser, E. (1990). Zero Defections: Quality Comes to Services. Harvard Business Review, 68(5), 105-110.

Rosenberg, M. J., and Hovland, C. I. (1960). Cognitive, affective, and behavioral components of attitudes. In M. J. Rosenberg, C. I. Hovland, W. J. McGuire, R. P. Abelson, and J. W. Brehm (Eds.), Attitude organization and change: An analysis of consistency among attitude components (pp. 114). New Haven, CT: Yale University.

Rosson, P., and Brooks, M. R. (2004). M\&As and Corporate Visual Identity: An Exploratory Study. Corporate Reputation Review, 7(2), 181-194. DOI: $10.1057 /$ palgrave.crr.1540219

Stone, E. F., and Hollenbeck, J. R. (1989). Clarifying some controversial issues surrounding statistical procedures for detecting moderator variables: Empirical evidence and related matters. Journal of Applied Psychology, 74(1), 3-10. DOI:10.1037/0021-9010.74.1.3

Van der Lans, R., Cote, J. A., Cole, C. A., Leong, S. M., Smidts, A., Henderson, P. W., . . Schmitt, B. H. (2009). Cross-National Logo Evaluation Analysis: An Individual-Level Approach. Marketing Science, 28(5), 968-985. DOI:10.1287/mksc.1080.0462

Van Riel, C.B.M., and van Hasselt, J.J. (2002), Conversion of organizational identity research findings into action, in Soenen, G. and Moingeon, B. (Eds), Corporate and Organizational Identities (pp. 156-174). Routledge, London: Waiguny.

Walsh, M. F., Winterich, K. P., and Mittal, V. (2010). Do logo redesigns help or hurt your brand? The role of brand commitment. Journal of Product \& Brand Management, 19(2), 76-84. DOI: 10.1108/10610421011033421

Wilkie, W. L. (1986). Consumer Behavior. New York, NY: Johm Wiley \& Sons.

Yoo, B., Donthu, N., and Lee, S. (2000). An Examination of Selected Marketing Mix Elements and Brand Equity. Journal of the Academy of Marketing Science, 28(2), 195-211. DOI:10.1177/0092070300282002

Zeithaml, V. A., Berry, L. L., and Parasuraman, A. (1996). The Behavioral Consequences of Service Quality. Journal of Marketing, 60(2), 31-46. DOI:10.2307/1251929 